\title{
SUMMER AND BREEDING RECORDS OF THE WHOOPING CRANE IN SASKATCHEWAN
}

DALE G. HJERTAAS, Saskatchewan Environment and Resource Management, 3211 Albert Street, Regina, Saskatchewan. S4S 5W6

Saskatchewan lies near the centre of the former Canadian breeding range of the endangered Whooping Crane. The Canadian Whooping Crane Recovery plan calls for establishment of a second migratory flock of Whooping Cranes breeding in Canada. Experience with reintroductions of other wildlife suggests the probability of success will be increased if this reintroduction occurs near the centre of the previous range. ${ }^{17}$ Understanding the former breeding range may therefore help to choose the general area for a reintroduction attempt. Even though the ecology of many sites has changed during the past 70 years, previous occupation by Whooping Cranes is one important clue to what constitutes suitability of a breeding site.

Allen concluded the biotic niche of the Whooping Crane was a shallow water region of ponds and sloughs, cattail, sedges, bulrush, pondweeds, spikerush and similar aquatic plants. ${ }^{1}$ For Saskatchewan, he listed seven known historic breeding records and concluded that these cranes nested in the aspen parkland belt and in the transition zone between parkland and grassland. ${ }^{1}$ No nest records were found for the forest or short grass prairie biomes in our province. ${ }^{1}$ Macoun suggested a wider distribution: "Thirty years ago this species was found in all the large marshes from the Red River to the Rocky mountains." ${ }^{27}$
In this review I evaluate breeding and summer records for the Whooping Crane in Saskatchewan. I include additional breeding sites not reported by Allen to provide a more complete understanding of the crane's historic distribution, abundance and habitat selection in Saskatchewan. ${ }^{1}$ This information may help in selection of eventual sites for a reintroduction attempt.

I also correct the location of the "famous last nest" found by Bradshaw in 1922, incorrectly reported as Muddy Lake by Allen. ${ }^{1}$

Methods Primary sources for this review were Allen's monograph, other published literature and Saskatchewan Museum of Natural History (SMNH) files of mostly unpublished observations which cover the period 1893 to $1976 .{ }^{1}$ These reports reflect the work of Fred Bradshaw, Fred Bard and other museum staff in tracking down observations of Whooping Cranes. Museum staff solicited reports from the public and recorded observations with as much detail as possible in reports carefully filed by year. Some of the reports are on special Whooping Crane Survey Report (WCSR) forms. Letters and other documents in the file have been cited in full with SMNH indicating their location. These files are now stored at the Canadian Wildlife Service (CWS) office in Saskatoon. 


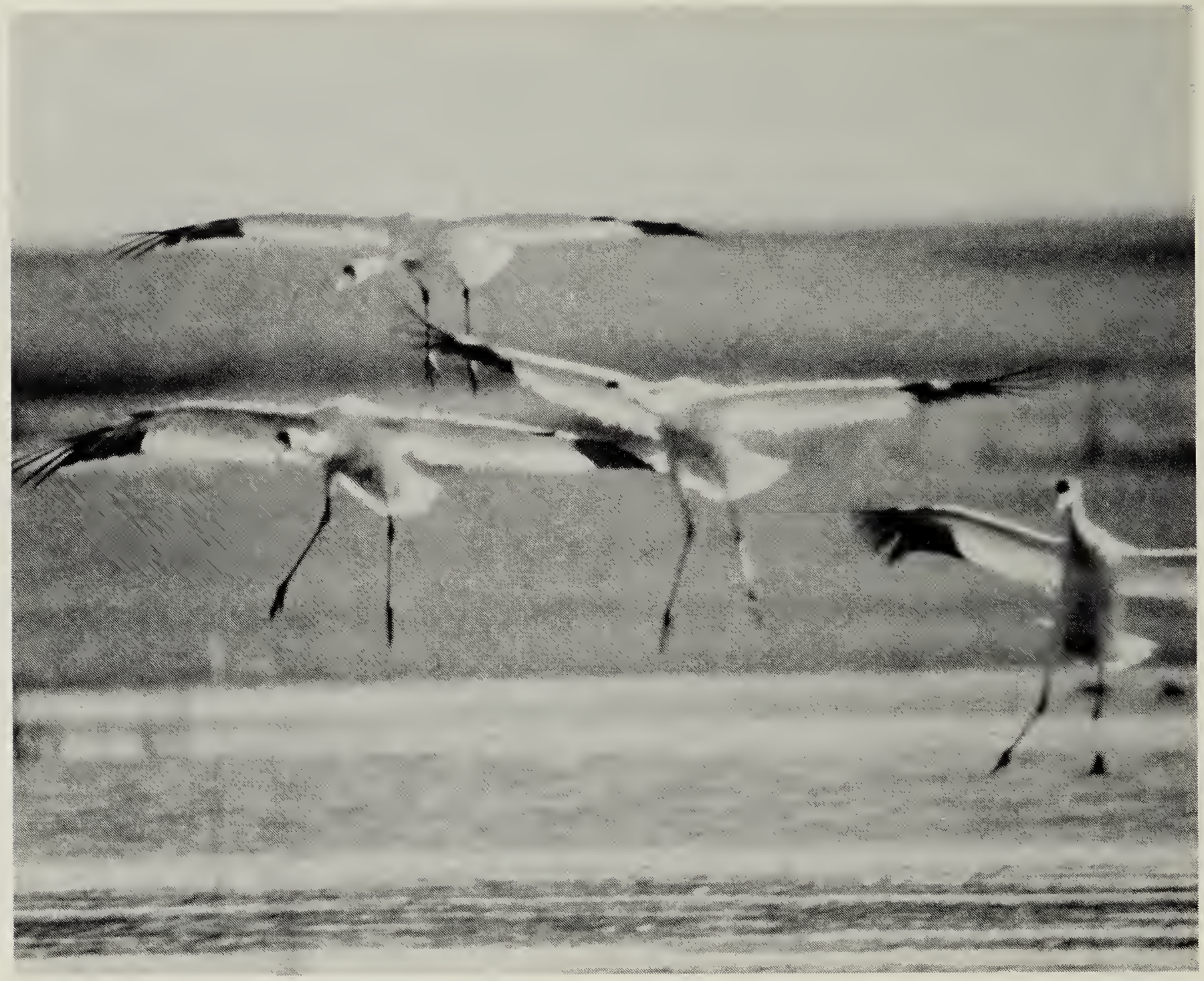

Coming in for a landing.

Lorne Scott

Since 1977 the Canadian Wildlife Service has compiled all sighting reports of the Whooping Cranes and classified them as accepted or unconfirmed. ${ }^{38}$ Only accepted records from this period have been included in this paper.

The records located fall into three categories: known breeding records (reference to a nest with eggs or a flightless chick or reported as a breeding record by an ornithologist), suspected breeding records, and summer records with no evidence of breeding. Summer records are defined as observations between 1 June and 20 August, which exclude the latest spring migrants and the earliest fall migrants (Brian Johns, pers. comm.). Nesting Whooping Cranes would have been sitting on eggs during May while nonbreeders are still in migration, so these May dates may have included some true summer observations.

Results All records are mapped on Figure 1. Numbers on the map match the numbered records in the text.

\section{Known Breeding Records:}

1. In May 1827, Richardson wrote that the Whooping Crane "frequents every part of the fur countries, though not in such numbers as the brown crane ... Its eggs are nearly as big as those of the swan, and of a bluish-white colour, with patches of brown." ${ }^{20}$ Richardson shot a Whooping Crane at Carlton, 7 May 1827, and this record is plotted there, but his observations of breeding birds may have been at one or several points during his travels.

2A. Macoun reported Whooping and Sandhill Cranes breeding in the 


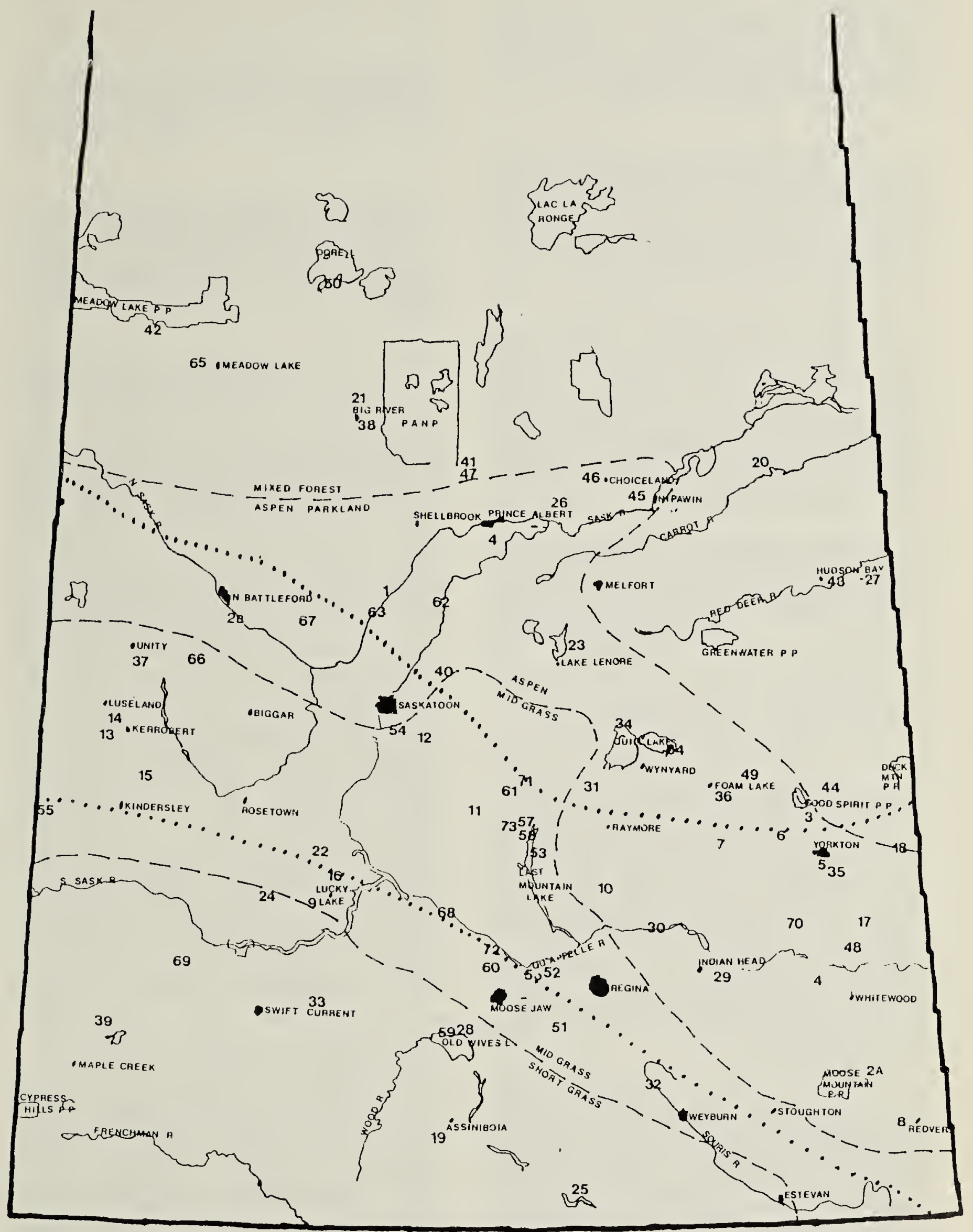

Figure 1. BREEDING, PROBABLE BREEDING AND SUMMER RECORDS OF THE WHOOPING CRANE IN SASKATCHEWAN, MAPPED WITH THE BREEDING RANGE AS MAPPED BY ALLEN AND VEGETATION ZONES. ${ }^{1,36}$

Legend

$1-16$

Known Breeding Records

$17-28$

Suspected Breeding Records

$29-73$

Summer Records

Boundaries of Vegetation Zones

Breeding Range After Allen (1952) 
marshes east of Moose Mountain 1 July 1880. ${ }^{24,25}$ These marshes would have been northeast of the Moose Mountain, probably near the present towns of Wawota or Dumas.

2B. Raine reported a nest with two eggs found by MacDonald near Battleford in 1884. The nest was described as a flat mass of rushes and grass about $3 \mathrm{ft}$. in diameter. ${ }^{34}$

\section{About 1955, William Fernie told} Cliff Shaw that in the 1890s he had seen a Whooping Crane nest with two white eggs on top of a muskrat house on Battersby's Lake (25-28-5W2), 6 mi. west of Gorlitz. ${ }^{19}$

4. Hugh Richardson collected a set of two eggs south of Prince Albert on 10 June 1896. The nest was a pile of marsh hay on the open prairie. ${ }^{27}$ This set of eggs is now in the New York State Museum, Albany, New York. ${ }^{1}$

\section{On 16 May 1900, two eggs were} collected near Yorkton by Cowboy Brown. ${ }^{1,10}$ This apparently is the egg set illustrated and described by Reed. ${ }^{35}$ These eggs are now in the Museum of Comparative Zoology at Harvard University, Cambridge, Mass. The nest was described as a mass of marsh hay on the prairie 3 ft. in diameter. ${ }^{19}$

\section{Peter Fernie told Stuart Houston} that one year near 1900 , a pair resided all summer in the "Fernie meadow" where a ridge runs into a big marsh adjacent to Cussed Creek, $4 \mathrm{mi}$. west and $1 \mathrm{mi}$. south of the village of Springside on NE7-27-6-W2. They laid a single large dirty white egg on a muskrat house. Fernie had also found two Sandhill Crane nests in the same meadow $\left({ }^{19}\right.$; C.S. Houston to Dale Hjertaas 27 January 1990).
7. A set of eggs was collected by Edward Arnold on 21 May 1901, at the foot of the Beaver Hills. This set is now in the collection of the Western Foundation of Vertebrate Zoology in Los Angeles (C. Stuart Houston, pers. comm.).

8. Harold H. Pittman was told in 1912 of a Whooping Crane nest at a large slough near Wauchope about $1902 .^{33}$

9. Ernest J. Demaine and Fred Swann found a nest in 1907, when establishing their homesteads near the present hamlet of Demaine. The area at this time was all virgin prairie. They had observed the pair of cranes make daily trips south and back again. Later in the spring only one of the birds made this trip. The two men decided one day to follow this bird north to where they believed it landed. About 2 mi. from their starting point they were met by a Whooping Crane which appeared wounded. They chased it for a considerable distance before it took to wing. The crane successfully lured the men away with its broken wing display on a second day as well. On the third day they realized the trick and went in the opposite direction to that in which the crane tried to lead them. They located a nest in a slough in 1 $\mathrm{ft}$. of water and some distance off shore. The other Whooping Crane was on the nest, but left as they waded out toward it, exposing two eggs (Dave Santy to Fred Bard, 24 April 1954 and 18 Sept 1954, SMNH).

Santy's letter indicates the cranes abandoned the nest as they did not see them again. However Bradshaw had recorded that only one egg hatched, and the chick was taken by Demaine, but apparently died the next day. ${ }^{9}$ Demaine also told 
Bradshaw about his unsuccessful attempts to trap and shoot these cranes.

The cranes did not return the following year and the slough was drained some years later.

10. H.M. Dahl of Davidson found a pair of adult Whooping Cranes with two young about the last week of June 1911, north of Southey (Tp. 2418-W2). He noted that there was then no farm within $2 \mathrm{mi}$. of the nest site (Bradshaw, undated).

11. In 1911, Reuben Lloyd of Davidson found a nest containing two eggs $20 \mathrm{mi}$. north of that town. ${ }^{1,2}$

12. Lester G. Moore observed a nest near Bradwell in 1912. One of the adult birds was killed.

13. Finley reported that his grandfather, J.V. Finley, and Joe Perry shot two and wounded one Whooping Crane in the fall of 1921 at Buffalo Coulee, $15 \mathrm{mi}$. due south of Luseland. ${ }^{12}$ They were later informed by an angry farmer near Buffalo Coulee that adult Whooping Cranes had nested there every year prior to 1921 and had raised a golden-coloured young one.

14. A series of Whooping Crane nest records come from Shallow Lake (Tp. 25-24-W3) between 1911 and 1928. Bradshaw called this lake, 9 miles northwest of Kerrobert, Balio! Lake, but I have used the current name of Shallow Lake. ${ }^{9}$ According to Archie Smith of Kerrobert, there were about 12 Whooping Cranes nesting there in 1911. Shallow Lake was then an alkaline marsh covering about 2000 acres. In 1912, Smith secured a young bird which became a family pet. It was killed by a coyote near their home in the fall. ${ }^{9}$
W.W. Smith, Archie's brother, found a nest there in 1921. There were two eggs, only one of which hatched (Bradshaw, undated). Bradshaw indicated this was the only pair in 1921 and the cranes raised one young. ${ }^{8}$

On 19 May 1922, Neil Gilmour, a provincial game guardian from Moose Jaw, observed a nest with two eggs at the same lake., ${ }^{1,6,29}$ Gilmour's search for these cranes and their nest is reported in detail in Bent. ${ }^{5} \mathrm{He}$ described the marsh as covering 3000 acres with a maximum depth of $3 \mathrm{ft}$. and grass growing to $2 \mathrm{ft}$. above the water. The nest, a mound of coarse grass and reeds rising one foot above the water, was in the centre of an open water area about $30 \mathrm{ft}$. in diameter. Four birds returned in 1923 and Gilmour saw a pair on 4 June $1925 .^{9}$

Hoyes Lloyd observed three birds here on 30 September 1922, and secured valuable natural history notes on their occurrence there for the previous 12 years. He noted that one of the birds he saw was a young of the year and referred to nests found there by Gilmour in 1922 and Smith in 1921; both were reported to have left the nests alone. He also reported that two were shot in the previous year (1921) and one was shot two years previously (1920). Local residents indicated there had been as many as 10-11 Whooping Cranes at this marsh in past years and were still eight three years ago (1919) (2 October 1922 report from Hoyes Lloyd, in camp, Plenty, SK, to the Commissioner. Cited in confidential file sent with a letter by J. B. Harkin, Commissioner, Dept. of the Interior, National Parks of Canada, to J.D. Soper, 23 November 1934).

This flock gradually decreased in numbers. The last reported nesting 
was observed in 1928 and reported by Archibald Smith in a 17 May 1932, letter to Bradshaw (SMNH). Bradshaw indicated that whoopers visited Shallow Lake in 1929, but there were none present in $1930 .^{7}$ The marsh was practically dried out in 1928 and had not reflooded by 1934..$^{9}$ This drought probably contributed to the crane's disappearance from the site. However, Lloyd's report of several shootings indicates that persecution also contributed to the decline.

Allen reported an observation by $E$. Margaret Estlin near Kerrobert in the summer of 1913. ${ }^{1}$ Pearson is cited as the source for this record. ${ }^{32}$ He reported that Estlin sent him a photograph of a living immature Whooping Crane from northern Saskatchewan "a few years ago." Presumably, Allen contacted Estlin to determine that this observation was from the Kerrobert area in 1913. As Kerrobert is only $9 \mathrm{mi}$. away, this record may also be from Shallow Lake.

15. A little more than $30 \mathrm{mi}$. southeast of Shallow Lake lies another shallow prairie marsh, Kiyiu (Eagle) Lake. I have used the name Eagle Lake in direct quotes, but otherwise use the modern Kiyiu Lake. The two are synonymous, since Kiyiu is one of the Cree names for eagle. Bradshaw reports finding a Whooping Crane nest here in $1922:^{9}$

"P. Hettle, Brock, reported in 1922 that for several years a small flock of Whooping Cranes had nested at Eagle Lake, Tp. 30-21-W3. The writer visited this lake May 28, 1922 , where three birds were observed and one nest containing three eggs was found. One young hatched May 30. One egg was infertile."

Bradshaw collected the hatched young and both eggs, one of which was infertile. The two eggs and some nest material recorded as collected by Bradshaw at Eagle Lake on 28 May 1922, are in the collection of the Saskatchewan Museum of Natural History. One egg has a small hole for removing contents, the other a larger cut consistent with one addled and one fertile egg (Dr. Paul James, Curator of Ornithology, SMNH, pers. comm.). Interestingly, Bradshaw reports accession of only one egg (addled). ${ }^{6}$

Whooping Cranes appear to have persisted at Kiyiu Lake until it dried out in 1930. Bradshaw (1930) wrote "On May 20 (1930) I was out to Eagle Lake, north of Neitherhill, where I found the Whooping Crane nesting site in 1922." The lake was dry, but Mr. Scholey of Neitherhill informed him there was water in the lake in 1929 and Whooping Cranes had bred there. David Watson of Dodsland, who lived near Kiyiu Lake, reported in 1932 that no Whooping Cranes had been seen or heard for two or three years and that the marsh was completely dried out. ${ }^{9}$

This 1922 nest record, which became famous as the "last nest," was somehow misplaced from Kiyiu to Muddy Lake and has been cited as a Muddy Lake nest record ever since. This error is first published in Allen (p. 61): "358. Muddy Lake (7 mi. S. of Unity); May 28-June 11922 (nesting 1 egg and $1 \mathrm{yg}$. coll.); Fred Bradshaw; Bent (1926); Fleming Coll. No. 30393 (ROMZ)". 'Allen also refers to this record at Muddy Lake on pages 24 and 39, listing it as the last known nesting site, the Wood Buffalo breeding area not having been discovered by 1952.

The location of this Whooping Crane nest at Kiyiu, not Muddy, Lake, is 
confirmed by Bradshaw's account of the discovery. He does not name the lake but indicates he walked to it from a farmhouse southwest of the Village of Plenty. ${ }^{8}$ Plenty is indeed just northeast of Kiyiu Lake. The record matches except that the chick is reported as hatching Monday, 29 May, rather than 28 May. Bradshaw has his dates one day off in this article, placing Sunday on 29 May rather than the actual 28 May. Otherwise this record matches the report in Bent of the nest being found 28 May and one egg hatched the next day. ${ }^{5}$

While Allen was the first to publish Muddy Lake as the location, he presumably received inaccurate information from some source. ${ }^{1}$ It is possible he followed the lead of Mitchell who wrote, "It is deemed advisable for the present to withhold exact locality of these breeding grounds," and deliberately falsified the location. ${ }^{29}$ However Allen correctly cites the location of the nest at Shallow Lake, also found in 1922, so it is unlikely that he falsified the location of the nearby Kiyiu nest to protect the most recent breeding site. ${ }^{1}$ It seems probable that Allen located the "last nest" at the wrong lake through an honest error. ${ }^{1}$

One of Allen's sources, Bent, ${ }^{5}$ does include a quote from Bradshaw describing the nest as a mound of sedges, gathered from around the nest, 4 to $5 \mathrm{ft}$. in diameter, and rising 15 to 18 in. above the water, and located 28 May 1922, but does not give a nest location.

Allen also cites a specimen at the Royal Ontario Museum (ROM). This may be the source of the error. ROM records for Whooping Crane chick \#37218 indicate it was collected 1 June 1922, when four days old, hav- ing hatched 28 May. It was collected at Kiyiu Lake $\left(51^{\circ} 37^{\prime \prime} \mathrm{N}, 108^{\circ} 52^{\prime \prime} \mathrm{W}\right)$ from a nest with two other eggs one of which was addled. The chick came to ROM as part of the J. H. Fleming collection. A note on the specimen card says "Report of the chief game guardian of Sask., Regina 1923, p. 14 refers to this specimen, and photo of nest on p. 15" (Letter Ross D. James, Associate Curator of Ornithology, ROM, to DGH, 19 April 1988). The cited report describes the nest with three eggs but does not provide a location. 6

How this Whooping Crane chick went from Bradshaw's collection at Kiyiu Lake to ROM is not clear, except that it was via the Fleming Collection. The original label, apparently in Mitchell's handwriting, reads:

"Grus americana, Hatched June 1, 1922. -2 other eggs in nest, 1 addled. Chick kept alive 4 days, not sexed. Loc: Muddy Lake, $7 \mathrm{mi}$. S. of Unity-W. of Saskatoon, Sask." (Brian Johns, CWS, to DGH 19 December 1988, and Ross James, ROM, to DGH 3 December 1992.)

Ross James (letter to DGH 3 December 1992) indicates a second label attached to the bird was added by J.L. Bailiie, former curatorial assistant at ROM. The label reads:

"Letter to L.L. Snyder from F. Bradshaw, the collector, dated 6 June 1955 , says this bird was not taken near Unity but at Eagle L (Kiyiu L.) south of Plenty $(50 \mathrm{mi}$. SSE of Unity)."

(L.L. Snyder was formerly a curator and Department Head at ROM.)

This label, on the specimen Allen references, is the probable source of 
the error. Bradshaw wrote to correct the error only after Allen's monograph was published in 1952.

Whether the error originated with Mitchell, or somewhere between him and Bradshaw, the mistake stuck. O. S. Pettingill, Jr., during his search for the Whooping Crane nest areas in 1946, visited the "last known nest site at Muddy Lake" with Bob Smith of the US Fish and Wildlife Service. ${ }^{28}$ Bard, Roy, Lahrman, and Godfrey have also cited Muddy Lake as the breeding locality. $3,37,23,16$

16. Luck Lake Heritage Marsh, restored in 1988, also apparently supported Whooping Cranes with nesting reported until 1929 and summering reports for 1932, 1935 and 1990. Luck Lake is $6 \mathrm{mi}$. north of the town of Lucky Lake. In notes the names seem to be used interchangeably, for example Bradshaw refers to Lucky Lake, $5 \mathrm{mi}$. NE of the town of that name, clearly the marsh we now call Luck Lake. I conclude that all reports referring to Luck Lake or Lucky Lake refer to what is now Luck Lake Heritage Marsh.

Bradshaw includes the following statement from Frank Miller of Birsay." "For six years prior to 1930 , from 2 to 7 were observed each year. Four were seen on the spring of 1929 and two young were hatched. The young are of a tan colour but look white when they fly. The only time one sees the black wing tips is when the birds are flying."

Roy (1954) cites a letter from Steve West (8 May 1964) indicating that Whooping Cranes nested for several years in the 1920s near Luck Lake. ${ }^{37}$ In spring there were never more than two adults together, but he saw four white and three buffy ones in August of 1929, even observing that two adults put a coyote to rout while the other two adults guarded the buff ones. He observed them again during the first week in October when the buffy young looked to be as big and strong as the parents. He never saw them in any subsequent year.

A confidential file attached to 23 November 1934, letter J.B. Harkin to J.D. Soper, cites a 23 February 1927 letter from Bradshaw indicating Neil Gilmour observed one pair at Lucky Lake on 10 June (presumably 1926) and one pair the previous year. Gilmour reports that in May 1925 he observed two pairs. ${ }^{14}$ "After carefully observing the actions of one pair of cranes through field glasses for almost an hour, I had no doubt from their constant movement forth and back over a very circumscribed area that they were engaged in the arduous task of nest building." Gilmore does not give a location, but the previous reference almost certainly places the observation at Luck Lake.

In the same file Reuben Lloyd of Davidson reported Whooping Cranes nesting at Lucky Lake in 1926 and, perhaps, 1927.

Bradshaw saw one Whooping Crane at Luck Lake 15, 27 and 28 May 1930. He watched it for some time, but saw no evidence that it was breeding, and concluded that it was a lone bird.?

Emil Lestin of Birsay, SK, reported observing two Whooping Cranes on stubble and marsh 12 August 1935. "The lake north of Luck Lake is dry, the Whooping Cranes are staying at the spring. I think they have young, but I am not sure" (WCSR, 1935, Emil Lestin).

The next summer Whooping Crane record for Luck Lake is of a yearling 
observed there 15 May to 22 June 1990. This crane was observed by many visitors during the official dedication of Luck Lake as a Heritage Marsh. It moved to NE17-14-2-W3 for 10 to 26 July (Brian Johns to DGH, 6 January 1993).

\section{Suspected Breeding Records}

17. E. H. M. Knowles of Regina reported Whooping Cranes nesting along Cut Arm Creek, 2.5 mi. west and 1 mile south of Bredenbury on 29-22-1-W2 in 1893 . $^{9}$

18. G. H. E. Mapleton of Shillingthorpe, a rural post office located on the northeast side of Shillingthorpe Lake, reported first seeing Whooping Cranes in 1894 when three pair stopped and bred on 1126-31-W1. In 1895, two pairs stayed all summer. The next year (1896) only three birds were seen. They left after about a week because much of the marsh had dried up. E.H.M. Knowles also reported Whooping Cranes nesting on Shillingthorpe Lake on $8-26-31-W_{1}$ in $1895 .{ }^{\circ}$ Section 8 is $1 \mathrm{mi}$. from Shillingthorpe Lake proper, but the topographic map shows two marshes of about 40 and 100 acres on this section.

\section{Macoun reported Whooping} Cranes likely breeding at Twelve Mile Lake, Wood Mountain, on 6 June $1895 .^{27}$

20. Silas Head recalled that there once were quite a few Whooping Cranes near Red Earth. ${ }^{30} \mathrm{He}$ remembered that his grandfather had seen lots of these birds out on the prairie before the white men came. Silas reported that when he was young (he was born about 1902) there were still a few Whooping Cranes near Kennedy Creek and remembered one hunter finding a pair and locating a nest. "It was not a very good nest, just a few sticks on the ground in the swamp." The nest held three eggs which were taken and eaten.

While the description does not sound like the large mound of grass described for other nesting Whooping Cranes, Head was remembering a nest he apparently did not see himself. The observation was when he was young and before a forest fire in the 1930 s, so may indicate a population of Whooping Cranes still present and breeding at Red Earth in the 1920s.

R.A. Hutton of Red Earth wrote to Bard (13 August 1945, SMNH) stating that older Indians are familiar with the white crane. It used to be quite numerous eight or ten years since. He indicated one man from Pine Bluff had seen one about five years ago, the last observation.

21. In the spring of $1916, \mathrm{H}$. Sharpe of Dore Lake and Big River saw two Whooping Cranes and also observed a nest from a distance. No details are given of the presumed nest. Sharpe also found a dead Whooping Crane in June 1916 on Black Duck Creek about $25 \mathrm{mi}$. north of Big River. $^{9}$

22. "Ernie Hedger (now of 1310 Colony Street, Saskatoon) recalls that his parents, about the years 191516 , used to speak of 'the big white birds' that frequented the hay slough on the west side of Section 2, Tp. 2610-W3. He remembers seeing the birds and their young during the summer months. The cranes also spent some time in the sloughs on the adjoining Sections, 3 and 10, 10 $\mathrm{mi}$. south and $5 \mathrm{mi}$. east of Dinsmore". 37 
23. N. T. Kingsley told P.A. Taverner and Hoyes Lloyd on 27 August 1920, in Humboldt, that Whooping Cranes nested on a small lake just east of Lake Lenore. These birds were seen there by himself the previous 8 October (1919) and were reported at the same place again this season (note from P. A. Taverner to Bradshaw, $S M N H)$.

24. On 1 June 1922, J.M.W. Bavin of the former rural post office of High Point, $4 \mathrm{mi}$. east and $10 \mathrm{mi}$. north of Kyle, Tp. 23-14-W3, wrote to the museum saying that a pair of Whooping Cranes used to nest in this district but the previous year (1921) they did not return. ${ }^{9}$

\section{R. Appleby of Roan Mine, SK, 10} mi. west and 2 mi. north of Minton, reported that a pair had nested on 20-3-21-W2 for four years (WCSR, 1930, R. Appleby). Bradshaw wrote to Appleby 29 October 1930 , asking for more details, but apparently did not receive a reply.

\section{Andrew Wytoski, a farmer from} Strong Pine, reported Whooping Cranes breeding on SE11 and 1251-22-W2 near the White Fox River and $5 \mathrm{mi}$. south of Foxford. His spring and fall counts for 1927,1928 and 1929 were 2 and 5,4 and 9, and, 8 and 16 , respectively (Whooping Crane Information, a 1932 file note $\mathrm{SMNH}$ ). He clearly gives this as a breeding location, but there are no comments on eggs or young so it is possible he was reporting spring and fall migrants.

\section{C.S. Van Tuyll, of Armit, then} called Meeks Siding, reported Whooping Cranes nesting in a marshy meadow $2 \mathrm{mi}$. long, lying 5 mi. east of Roscoe, apparently in 1932. On 20 May 1935, he visited the marshes again, but did not see any cranes (WCSR, 1935, C.S. Van Tuyll).

28. In a letter to Dewey Soper, 19 January 1948, D.H. Rendick of Lacombe, Alberta, reported "we actually saw 1 pair nesting and another pair at the far end of the lake from their actions we could gather that they were already hatched and were hiding their young." This observation, from either 1933 or 1934 , was at a small lake near Old Wives Lake.

\section{Summer Records}

29, 30. "This beautiful bird is common in the Qu'Appelle Valley and in the Touchwood Hill range." ${ }^{18}$ Hind explored southern Saskatchewan in 1858. He saw the first Whooping Cranes on 14 July at "Weed Ridge," probably about $5 \mathrm{mi}$. east-southeast of present Grenfell (Dr. C.S. Houston, pers. comm.). On 21 July, on the marshes upstream from Pasquia Lake he noted the "white crane" in flocks of four and seven.

31. On 12 or 13 August 1872, Frank Fleming and John Macoun saw two white cranes on a ridge on the prairie south of Quill Lake. Frank Fleming and Willie, an assistant, chased the cranes along the ridge on horseback. "One of the cranes took to flight and the other one, which may have been a young one and unable to fly, ran like a race horse. Willie went after it and eventually ran up close enough to throw his lariat around its head and brought it to the ground. The old one returned and seemed to attack Willie but was beaten off by Frank Fleming."26

Grant reports this story with a few differences. ${ }^{16}$ He reports that Willie killed the crane with a stone. The cranes were reported to rise from a wet marsh near the road, not a ridge. 
Grant refers to the one killed as a young one. Extended wings measured more than $6 \mathrm{ft}$. from tip to tip. The crane was eaten at camp that night and reported to be very good.

The fact the crane was flightless could indicate a young bird and so indicate nesting nearby. Grant refers to it as a young bird and Macoun says it may have been a young one. However, neither Grant nor Macoun mention the rusty tinge a young Whooping Crane would have in midAugust, in fact both describe two white cranes. Adults do experience a flightless period while moulting, so flightlessness does not necessarily mean a young bird. By August 13 both adults and young should be able to fly, hence this may have been an injured adult.

Macoun and Fleming crossed the prairie between Kutawagan Lake and Big Quill Lake on 13 August. However, Grant places the incident on 12 August, when they were still south of the Touchwood Hills, about $12 \mathrm{mi}$. west of the present site of Ituna. $^{16}$

32. S.J. Taylor of Regina indicated that Whooping Cranes were quite common in the Yellowgrass Marsh from 1898 to 1905 but had no reason to believe they had been seen there during the subsequent 20 years (i.e., between about 1910 and 1930). ${ }^{9}$ । expect Taylor refers to cranes being common in summer, but it is possible he meant common as migrants.

33. Raine quotes MacDonald as sighting a single Whooping Crane flying toward Rush Lake on 13 June $1891 .{ }^{34}$

34. R.M. Barnes of Lacon, Illinois, observed a Whooping Crane at Big Quill Lake in 1909. His report is quoted by Ferry as follows: "June 14 we saw a splendid specimen of this species standing on the wide muddy flat at the north end of Big Quill Lake. We examined it carefully with our glasses, and endeavoured to stalk it. This was the only specimen seen.."11

35. R. Grieve of Yarbo reported "There were two I used to see when I was ploughing that led me to believe they nested somewhere close. This was near 1 large marsh southwest of the town of Rokeby. They used to go through some very funny antics on a small knoll in a hay meadow. These dances would go on early in the morning and late evening." The report is indicated as 25 to 30 years ago which probably indicates between 1900 and 1910. It could be a spring migration observation, but Yarbo's report indicates repeat observations, and he suspects they may have been nesting. I thus conclude this is probably a summer record.

36. Two Whooping Cranes at 27-2911-W2, $2 \mathrm{mi}$. east and $7 \mathrm{mi}$. south of Foam Lake, through the summer of 1910 , but were not seen there in subsequent years. H. C. Grose of Lucky Lake. $^{9}$

37. W. Huber of Unity found a Whooping Crane which had been shot at Muddy Lake (Tp. 38-22-W3) on 27 April 1921. The mate of the dead whooper remained in the area for several months. ${ }^{9}$

38. Seven Whooping Cranes, flying over Ladder Lake near Big River. 10 August 1927. Mr. G.H. Cartwright. ${ }^{9}$

39. Robert Perrin of Maple Creek reported seeing "a few" in early August, apparently of 1928 or 1929 , east of Big Stick Lake. ${ }^{9}$ 
40. An adult, sex not recorded, was collected at Vonda on 13 June 1930 and held at the Saskatchewan Museum of Natural History, then sent to the Museum of British Columbia (Dr. Paul James, pers. comm.).

41. Two Whooping Cranes circling over Emma Lake. Summer, 1932. John N. Hackett of Christopher Lake. ${ }^{9}$

42. One Whooping Crane feeding on stubble near the Beaver River, August 1936 and one flying near the Beaver River (5-62-21-W3), July 1945. George Bauman of Golden Ridge (WCSR, 1945, Mr. George Bauman).

43. In summer of 1937 and 1938 three and five Whooping Cranes were seen by Mrs. L. J. Bayet of Hudson Bay. The cranes spent the summer on a field gone back to voluntary sweet clover located $8 \mathrm{mi}$. southeast of Hudson Bay on 2-44-3W2. There was a marsh not far away. Bayet reports they are quite unafraid of men (WCSR, 1945, L. J. Bayet).

44. A Whooping Crane along the White Sand River at 21-30-3-W2, 3 mi. east and 2 mi. south of Canora. June 1945. Observed by students and reported by Pearl J. Achtemichuk of Canora, Sask. (WCSR, 1945, Pearl Achtemichuk).

45. Three Whooping Cranes. Seen almost daily from 29 April to 13 June 1945 , in the vicinity of Campbell Lake 12 mi. west of Nipawin. J.M. Lyons, J.H. Wark and M.G. Street. $^{21,39}$

46. Ernest Johnson saw one Whooping Crane near Snowden during early June 1942. Garth Harrison observed one in the same area about
mid-June 1946 and Jack Carson had a pair near his home $4 \mathrm{mi}$. away all summer, $1946 .^{39}$ Walkinshaw searched this area by air and foot in 1947 , but located no whoopers.

47. One Whooping Crane. Flushed from reeds in a marsh at the north end of Christopher Lake. Mid-July 1945. W.D. Roberts (Whooping Crane Investigation Form, 1945, by W.D. Roberts, Prince Albert, SMNH).

48. One Whooping Crane. Near Stockholm. June 1947. Mrs. E. Meadows. ${ }^{1}$

49. One Whooping Crane. Near Invermay. Late May or early June 1948. M.S. Dimmick. ${ }^{1}$

50. One whooper on the shore of Dore Lake (13-66-9-W3). 1 and 2 June 1954. Observed by George Roberts, a DNR towerman, who was confident this was not a swan or a pelican (Letter B.H. Matheson, District Supervisor, Department of Natural resources, to Bard, 14 June 1954).

51. One yearling Whooping Crane at 10-12-23-W2, $2.5 \mathrm{mi}$. south of Avonlea. 23 and 24 June 1954. Photographed by Fred Lahrman of the SMNH (WCSR 1957 by F.W. Lahrman).

52. One Whooping Crane at 10-1823-W2, $9 \mathrm{mi}$. south and 1 west of Disley. 24 June 1954. G. Schmidt (WCSR 24 June 1957 by Rex Gary Schmidt).

53. One Whooping Crane on W7-2723-W2 near the east shore of Last Mountain Lake, $11 \mathrm{mi}$. west of Govan. 24 August 1954. R. Blackwood (Whooping Crane Sightings in Saskatchewan 1954-58, 7 pp. file in SMNH). 
54. Two adult Whooping Cranes near Haultain, June 1956. Bill Hyshka (Letter Brian Johns to DGH, 19 Dec, 1988). Photographed by Bard 25 June $1956 .^{2}$

55. Bard reported two Whooping Cranes photographed at Alsask in April 1956 by Gordon Duane and indicates he photographed two birds here for the museum. ${ }^{2}$ No date is given but he refers to this as a summer record.

56 . One yearling whooper on 10-1823-W2, $2 \mathrm{mi}$. north and $3 \mathrm{mi}$. east of Stony Beach, 23 and 24 June 1957. Rex Gary Schmidt \& Fred Lahrman (WCSR, 1957, Fred Lahrman; WCSR, 1957, Rex Gary Schmidt).

57. One Whooping Crane at Simpson, 6, 27 and 30 May and 24 and 28 August 1958, and presumably present all summer (Bard 1959).

58. One adult Whooping Crane at Imperial Beach, Last Mountain Lake. 22 June 1964. Margaret Belcher, S. R. Belcher and C. S. Houston (C. S. Houston, pers. comm.).

59. Two Whooping Cranes on E1214-01-W3 on the shore of Old Wives Lake directly south of Old Wives village. 22 July 1969. Dick Yancey, confirmed by RCMP (Brian Johns to DGH, 19 December 1988).

60. One Whooping Crane feeding in a wheat field within 150 yards of tractor on E17-18-27-W2, 4 mi. west and $3 \mathrm{mi}$. south of Tuxford. 3 August 1976. Eldon Beasley (Brian Johns to DGH, 19 December 1988).

61. One whooper at slough on section 9-31-26-W2, $4 \mathrm{mi}$. west of Renown. 7 July 1977. A. Hansen, US Fish and Wildlife Service ${ }^{38}$ (Brian Johns to DGH, 19 December 1988).
62. Two adult whoopers on 33-4301-W3, 3 mi. north of Batoche. 7 to 20 August 1977. Mrs. B. Berg and Conservation Officer R. Brunt ${ }^{38}$ (Brian Johns to DGH, 19 December 1988).

63. Two Whooping Cranes on a wooded island in the North Saskatchewan River, $11 \mathrm{mi}$. north of the Petrofka Bridge. 11 August 1977. K. Steuart $^{38}$ (Brian Johns to DGH, 19 December 1988).

64. One whooper near Little Quill Lake at a Ducks Unlimited project on Milligan Creek, Township 33-14-W2. 30 May to 31 August 1981. Many observers $^{38}$ (Brian Johns to DGH, 19 December 1988).

65. One Whooping Crane on SW2159-19-W3, $12 \mathrm{mi}$. west of Meadow Lake. 24 July to 1 August 1988. Y. and $L$. Cockrum. While this sighting was not confirmed it may have been the same bird as the next record (Brian Johns to DGH, 6 January 1993).

66. One adult whooper with 10 Sandhill Cranes. Flat Lake (2 mi. S of Wilkie) 24 August 1988. R.H. Kerbes and Gary Wobeser (locals reported bird present since August 3) (Brian Johns to DGH, 19 December 1988).

67. Two yearling Whooping Cranes, identifiable by leg bands, spent the summer of 1989 in Saskatchewan, moving several times from the Cudworth area (28-31 May) to Speers (522 June) to Radisson Lake (4 July) and back to Cudworth (10 July to 24 October) (Brian Johns to DGH, 6 January 1993).

68. Two yearling whoopers on Eyebrow Lake 15 May to 11 September 1989. Usually found near the 
upstream end of this marsh. One unbanded adult, assumed to be one of the two which had summered there in 1989, spent 30 May to 8 October 1990 at Eyebrow Lake (Brian Johns to DGH, 6 January 1993).

69. One yearling whooper, banded green-white-green on left leg, green on right. NE19-18-18-W3, $3 \mathrm{mi}$. south of Cabri, 15 May to $10 \mathrm{Sep}$ tember 1989 (Brian Johns to DGH, 6 January 1993).

70. One yearling whooper on Surprise Lake, SE01-21-7-W2. 17 May to 3 August 1990 (Brian Johns to DGH, 6 January 1993).

71. One whooper on 7-32-23-W2, 10 mi. NE of Watrous. 13 August to 15 September 1990 (Brian Johns to DGH, 6 January 1993).

72. One Whooping Crane on SW1420-28-W2, $3 \mathrm{mi}$. west and $5 \mathrm{mi}$. north of Marquis. 12 to 25 August 1991 (Brian Johns to DGH, 6 January 1993).

73. One whooper on Bullrush Lake, 11-28-25-W2, near Imperial, 29 July 1992. Relocated north end of Last Mountain Lake 17 August until 25 September (Brian Johns to DGH, 6 January 1993).

Discussion The Whooping Crane appears to have been a widespread, although probably not abundant, nesting species in Saskatchewan. Twenty-nine known and suspected breeding records are spread from the southern mixed forest to the short grass prairie as mapped by Richards and Fung. ${ }^{36}$ The greatest number of sites, 13 , are in the aspen parkland. Three are north of the parkland in the southern parts of the mixed forest and one, Richardson's report, may indicate breeding in the forest, parklands, or both. Eight of the records come from the mid-grass prairie, and four from the short grass prairie as mapped by Richards and Fung. ${ }^{36}$ Other authorities place the short grass border further south. For example, following the maps in the prairie Conservation Action Plan would place these four in the mixed grass prairie. This distribution generally agrees with Allen's conclusion that the aspen parkland and adjacent transition areas were the major breeding areas. However the breeding range extended further north, to include suitable marshes in the southern part of the forest, and further south to include more marshes of the grasslands than shown by Allen's range map. ${ }^{1}$

Within what is now agricultural Saskatchewan, Whooping Cranes appear to have nested wherever suitable, large, shallow marsh areas were found. The report of 12 Whooping Cranes nesting at Shallow Lake in one year suggests that the large marshes of the grassland were excellent breeding habitats, at least until the 1930s drought. Nest records from areas like Wauchope suggest that smaller wetlands were also used.

Nest sites are sometimes described as prairie, more often as a marshy meadow or shallow marsh. Several nests were on top of muskrat houses. A consistent feature of nest sites seems to be shallow water with emergents from which a nesting platform can be built. Most areas appear to include a significant shallow water area where cranes foraged.

The scattering of breeding sites across the province suggests that many other shallow wetlands were also used. Estimating the total population is difficult not only due to the 
paucity of data, but because the species was declining in numbers by 1870 , before European settlement of Saskatchewan and prior to all records cited here except Richardson's. ${ }^{1}$ The lack of breeding records from the northwest part of the agricultural zone may be a reflection of later settlement of this area rather than unsuitability of the habitat.

Suitable wetlands in Saskatchewan were once much more extensive than at present. A presettlement Saskatchewan population of at least 200 and, perhaps, more than 1000 pairs seems reasonable, unless many habitats were unoccupied due to limitations of winter habitats.

The former wide distribution of the Whooping Crane in southern Saskatchewan suggests that almost any marsh complex offering extensive areas of emergent vegetation suitable for nest building and shallow areas for foraging could support Whooping Cranes. If a reintroduction is considered, selection of the actual site should consider current habitat quality and security, isolation, area for possible population expansion, access for wildlife management staff, sandhill crane populations, crop damage and hunting, as well as political and economic factors. The reports from Kiyiu, Shallow and Luck Lakes all mention the lakes drying out in the 1930s drought. Thus the drought may have dealt a last blow to these southern populations. Water supply must be a consideration when selecting a release site.

One area which could be investigated is the Yorkton wetlands complex south of Yorkton. There are several nest records from this region, most of this large wetland complex is controlled by Ducks Unlimited and the wetlands are mostly surrounded by pastureland and so quite isolated, even though a city is only a few miles to the north. The extensive marshes of the Cumberland Delta offer a second possible release area. Although there are no confirmed breeding records from this area, there is a possible record from Red Earth and Richardson's comment that they frequent every part of the fur countries suggests they were found in the Saskatchewan River Delta, a key part of the fur country.

The Quill Lakes-Last Mountain Lake area would appear to be attractive in most respects, but Sandhill Crane hunting in this area and crop depredation by Sandhill Cranes argue strongly against reintroducing Whooping Cranes in this area. Further west Luck Lake is one of the most recently utilized sites and is now a managed Heritage Marsh with a secure water supply. The principal weakness to this site is the shortage of suitable adjacent wetlands for population expansion.

The population nesting in Saskatchewan in the early part of this century was a significant portion of the world total. Reported nesting populations for 1911 and 1912 total 20 cranes. Considering that sites such as Kiyiu Lake and Luck Lake which were reported later also probably supported cranes, suggests at least 30 Whooping Cranes in Saskatchewan in 1912. Winter counts at this time indicate a total population, including 32 Louisiana birds, of only 88. ${ }^{1}$ Summer records from the $1930 \mathrm{~s}$ and 1940s suggest that when the crane population reached its low of 15 in 1941, a few Whooping Cranes may have been summering in Saskatchewan, not Wood Buffalo. If so, the founders for the Wood Buffalo population may be more 
restricted even than that low population suggests.

Acknowledgements I wish to acknowledge with deep appreciation the assistance and strong encouragement I received to complete this paper from Dr. C. Stuart Houston and the assistance in locating records provided by Ruby Apperly and Dr. Paul James, Saskatchewan Museum of Natural History, Brian Johns, Canadian Wildlife Service, and Dr. Ross D. James, Royal Ontario Museum.

1. ALLEN, R.P. 1952. The Whooping Crane. Research report \#3 of the $\mathrm{Na}$ tional Audubon Society. National Audubon Society, NY, NY.

2. BARD, F.G. 1956. Whooping Cranes in southern Saskatchewan in 1956. The Blue Jay 14:81.

3. 1958. Whooping Cranes, 1958 The Blue Jay 16:11-14.

4. 1959. Annual report of the Whooping Cranes in Saskatchewan, 1958. The Blue Jay 17:9-11.

5. BENT, A.C. 1926. Life histories of North American marsh birds. Smithsonian Institution United States National Museum Bull. 135. Dover Reprint Edition. Dover Publications, Inc. NY, NY.

6. BRADSHAW, Fred. 1923. Report of the Chief Game Guardian on matters relating to game protection, the administration of the Game Act, and the development of the provincial museum during year ended April 30, 1923. pp. 268-314 in Eighteenth annual report of the Department of Agriculture of the Province of Saskatchewan for the twelve months ended April 30, 1923. J. W. Reid, Kings Printer. Regina.

7. 1930. Whooping Crane. Unpublished report. 3pp. SMNH files.

8. 1956. The home of the Whooping Crane. The Blue Jay 14:76-8.

9. Undated. Whooping Crane information (Saskatchewan). Unpublished list of reports received at the SMNH, unsigned by writer identifiable as
Bradshaw by personal accounts, $15 p p$.

10. COOKE, W.W. 1914. Distribution and migration of North American rails and their allies. U.S. Department of Agriculture Bull. \#128.

11. FERRY, J.F. 1910. Birds observed in Saskatchewan during the summer of 1909. Auk 27:185-204.

12. FINLEY, K.J. 1972. A 1921 photo of a Whooping Crane. The Blue Jay 30:151-152.

13. GILMOUR, Neil. 1923. Report of Neil Gilmour, Provincial Game Guardian. Pp. 290-293 in Eighteenth annual report of the Department of Agriculture of the Province of Saskatchewan for the twelve months ended April 30, 1923. J.W. Reid, Kings Printer. Regina.

14. 1926. Report of Neil Gilmour, Provincial Game Guardian. Pp. 21-? in Bradshaw (1926) Report of the Game Commissioner on matters relating to game protection, the administration of the Game Act, and the development of the provincial museum during year ended April 30, 1926. J.W. Reid, King's Printer, Regina.

15. GODFREY, W.E. 1986. The birds Of Canada, revised edition. National Museums of Canada, Ottawa.

16. GRANT, G.M. 1873. Ocean to ocean - Sanford Fleming's expedition through Canada in 1872 - being a diary kept during a journey from the Atlantic to the Pacific with the expedition of the Engineer-in-Chief of the Canadian Pacific and Intercolonial Railways. John Campbell \& Son, Toronto.

17. GRIFFITH, Brad, et al. 1989. Translocation as a species conservation tool: status and strategy. Science 245:47780.

18. HIND, H.Y. 1860. Narrative of the Canadian Red River Exploring Expedition of 1857 and the Assiniboine and Saskatchewan Exploring Expedition of 1858. Vol. 1. Longman, Green, Longman and Roberts, London, England.

19. HOUSTON, C.S. 1972. Early Whooping Crane nest records near Yorkton, Saskatchewan. The Blue Jay 30:1523. 
20. - (Editor). 1984. Arctic ordeal: the journal of John Richarson, surgeonnaturalist with Franklin 1920-22. McGill-Queen's University Press, Kingston and Montreal.

21. HOUSTON, C.S. and M.G. Street. 1959. The birds of the Saskatchewan River, Carlton to Cumberland. Sask. Nat. Hist. Soc. Spec. Pub. \#2, Regina, Sask.

22. JOHNS, B.W. 1987. Whooping Crane sightings in the Prairie Provinces, 1979-85. CWS Progress Notes \#169.

23. LAHRMAN, F.W. 1972. The Whooping Crane in Saskatchewan. The Blue Jay 30:146-150.

24. MACOUN, John. 1881. Extract from a report of exploration by John Macoun, M.A., F.L.S. Report of the Department of the Interior for 1980 , Sessional Papers \#3, pp. 8-40.

25. 1883. Manitoba and the Great North West: the field for investment. The home of the immigrant. Thomas C. Jack, Edinburgh \& Glasgow.

26. MACOUN, John. 1979. Autobiography of John Macoun Canadian explorer and naturalist 1831-1920. 2nd ed. Ottawa Field-Naturalists Club Special Publication \#1, Ottawa.

27. MACOUN, John and J.M. Macoun. 1909. Catalogue of Canadian birds. Canada Dept. of Mines, Geological Survey Branch, Ottawa.

28. MCCOY, J.J. 1966. The hunt for the Whooping Cranes: a natural history detective story. Lothrop, Lee \& Shepard Co., Inc. N.Y., N.Y.
29. MITCHELL, H.H. 1924. Birds of Saskatchewan. Can. Field-Naturalist 38 : 101-18.

30. MYER, DAVID, SILAS HEAD and DONALD MCKAY. 1974. Indian bird identification and Whooping Cranes at Red Earth, Saskatchewan. The Blue Jay 32:168-171.

31. PARKER, J.L. 1957. An attack on man by a Whooping Crane. The Blue Jay 15:63.

32.PEARSON, T.G. 1922. Whooping Cranes in Texas. Auk 30:412-3.

33. PITTMAN, H.H. 1956. Sandhill Cranes in retrospect. Nature Magazine 49(5):237-239.

34. RAINE, Walter. 1892. Bird-nesting in North-West Canada. Hunter, Rose and Co., Toronto, Canada.

35. REED, C.A. 1904. North American birds eggs. Doubleday, Page \& Company. N.Y., N.Y.

36. RICHARDS, J.H., and K.I. FUNG 1969 Atlas of Saskatchewan. University of Saskatçhewan, Saskatoon, SK.

37. ROY, J.F. 1964. An introduction to the birds of the Elbow. A list prepared for the annual summer meeting of the Saskatchewan Natural History Society, June 5-7, 1964.

38. STEPHEN, W.J.D. 1979. Whooping Crane sightings, Prairie Provinces 1977 and 1978. The Blue Jay 37:163168.

39. WALKINSHAW, L.H. 1949. Apparent observations of the Whooping Crane in central Saskatchewan. Can. FieldNaturalist 63:78-80.

The average flowering date for the Crocus or Pasque-flower is 11 April at Winnipeg, 18 April at Saskatoon and 25 April at Edmonton. R.C. Russell. 1962. Canada Plant Disease Survey 42:162-166. 